\title{
China's WTO Accession and the Impact on Its Large Manufacturing Enterprises
}




\section{This page is intentionally left blank}




\author{
East Asian Institute (EAl) \\ Contemporary China Series No. 30
}

\title{
China's WTO Accession and the Impact on Its Large Manufacturing Enterprises
}

\section{Guy LIU Shaojia}

EAST ASIAN INSTITIE

National Universily of Singapore 


\section{Published by}

World Scientific Publishing Co. Pte. Ltd.

PO Box 128, Farrer Road, Singapore 912805

USA office: Suite 1B, 1060 Main Street, River Edge, NJ 07661

UK office: 57 Shelton Street, Covent Garden, London WC2H 9HE

and

Singapore University Press Pte. Ltd.

Yusof Ishak House, National University of Singapore

10 Kent Ridge Crescent, Singapore 119260

\section{THE MYSTERY OF CHINA'S FALUN GONG: \\ Its Rise and Its Sociological Implications \\ East Asian Institute (EAI) Contemporary China Series No. 22}

Copyright $\odot 1999$ by World Scientific Publishing Co. Pte. Ltd. and Singapore University Press Pte. Lid.

All rights reserved. This book, or parts thereof, may not be reproduced in any form or by any means, electronic or mechanical, including photocopying, recording or any information storage and retrieval system now know'n or to be invented, without written permission from the Publishers.

For photocopying of material in this volume, please pay a copying fee through the Copyright Clearance Center, Inc., 222 Rosewood Drive, Danvers, MA 01923, USA. In this case permission to photocopy is not required from the publishers.

ISBN $981-02-4208-5(\mathrm{pbk})$

Printed in Singapore. 


\section{CONTENTS}

1. Enterprise Reform and WTO Accession 2

2. Methods of Assessment $\quad 8$

3. Which Industry and State Firms Can Survive after WTO Accession?

3.1. Type I Market

3.2. Type II Market

3.3. Type III Market

4. Conclusions $\quad 54$

Appendix 1: Proof of the Claim 2 in Section 2

Appendix 2: China's Import Duty on Some Popular

Goods, 1998-2000

Appendix 3: Overview of China's Light Industry \& Market Share Structure

Appendix 4: Who Survives Longer: Can a Diversified Ownership Structure be Sustainable in the Bicycle Sector after WTO Accession?

A competitive evolution of market share and ownership structure of the top 10 firms group over 1992-1999 